Кудаева 3. Ж. Этические предания адыгов : жанровые критерии и основные мотивы / 3. Ж. Кудаева, К. Н. Паранук, А. П. Голодова // Научный диалог. - 2021. — № 7. — С. 183197. - DOI: 10.24224/2227-1295-2021-7-183-197.

Kudaeva, Z. Zh., Paranuk, K. N., Golodova, A. P. (2021). Ethical Traditions of Adyghe: Genre Criteria and Main Motives. Nauchnyi dialog, 7: 183-197. DOI: 10.24224/2227-1295-2021-7-183197. (In Russ.).

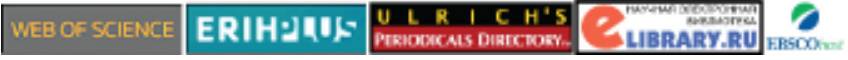

Журнал включен В Перечень ВАК

\section{Этические предания}

\section{адыгов: жанровые}

\section{критерии и основные}

\section{мотивы}

Кудаева Зинаида Жантемировна ${ }^{1}$ orcid.org/0000-0002-0255-4432 доктор филологических наук, профессор кафедра русской и зарубежной литератур zina_777@bk.ru

\section{Паранук Кутас Нуховна 2} orcid.org/0000-0001-5257-1188 доктор филологических наук, профессор kutas01@mail.ru

\section{Голодова Анастасия Павловна 1} orcid.org/0000-0002-9171-8645 аспирант кафедра русской и зарубежной литератур anastasiia.golodova@mail.ru

${ }^{1}$ Кабардино-Балкарский государственный университет им. Х. М. Бербекова (Нальчик, Россия)

${ }^{2}$ Адыгейский государственный университет (Майкоп, Россия)

\section{Ethical Traditions of Adyghe: Genre Criteria and Main Motives}

Zinaida Zh. Kudaeva ${ }^{1}$ orcid.org/0000-0002-0255-4432

Doctor of Philology, Professor

Department of Russian and Foreign Literatures zina_777@bk.ru

Kutas N. Paranuk ${ }^{2}$ orcid.org/0000-0001-5257-1188 Doctor of Philology, Professor kutas01@mail.ru

Anastasia P. Golodova ${ }^{1}$ orcid.org/0000-0002-9171-8645

Post-graduate student

Department of Russian and Foreign Literatures anastasiia.golodova@mail.ru

${ }^{1}$ Kabardino-Balkarian State University named after H. M. Berbekov

(Nalchik, Russia)

${ }^{2}$ Adyghe State University (Maykop, Russia)

(C) Кудаева 3. Ж., Паранук К. Н., Голодова А. П., 2021 


\section{ОРИГИНАЛЬНЫЕ СТАТЬИ}

\section{Аннотация:}

Ставится задача изучения этических преданий, рассматриваемых в качестве одной из специфических жанровых разновидностей адыгской исторической прозы. Актуальность исследования обусловлена назревшей потребностью создания жанровой классификации адыгской несказочной прозы. Отмечается, что в этой связи изучение этических преданий является одним из необходимых этапов в решении данной проблемы. Основная цель статьи состоит в определении жанровых признаков и основных функций, выявлении основных мотивов и образов, присущих этическим преданиям. Используются культурно-исторический и сравнительно-исторический методы исследования. Анализируются общественно-исторические условия и факторы, способствовавшие возникновению жанра этических преданий, выявляются различные группы преданий, прослеживается процесс трансформации нравственноэтических принципов и норм, определяются наиболее продуктивные сюжетообразующие мотивы. Показано, что дифференцирующим признаком этических преданий является их когнитивная и социорегулятивная функции. Утверждается, что основная их цель - репрезентация идеальных форм и стандартов межличностного поведения, которые должны способствовать формированию и утверждению моральных, этических и этикетных норм, существовавших в адыгском традиционном обществе.

\section{Ключевые слова:}

адыги; этические предания; жанр; мотив; функция; этика; этикет; адыгэ хабзэ.

\section{ORIGINAL ARTICLES}

\section{Abstract:}

The task is to study ethical legends considered as one of the specific genre varieties of the Adyghe historical prose. The relevance of the research is due to the urgent need to create a genre classification of the Adyghe non-fairytale prose. It is noted that in this regard, the study of ethical traditions is one of the necessary stages in solving this problem. The main goal of the article is to determine genre features and main functions, to identify the main motives and images inherent in ethical legends. Cultural-historical and comparative-historical research methods are used. The socio-historical conditions and factors that contributed to the emergence of the genre of ethical legends are analyzed, various groups of legends are identified, the process of transformation of moral and ethical principles and norms is traced, the most productive plot-forming motives are determined. It is shown that the differentiating feature of ethical traditions is their cognitive and socioregulatory functions. It is argued that their main goal is to represent ideal forms and standards of interpersonal behavior, which should contribute to the formation and approval of moral, ethical and etiquette norms that existed in the Adyghe traditional society.

Key words:

Adyghe; ethical traditions; genre; motive; function; ethics; etiquette; adyge khabze. 


\section{Этические предания адыгов: жанровые критерии и основные мотивы}

() Кудаева 3. Ж., Паранук К. Н., Голодова А. П., 2021

\section{1. Введение}

В современной адыгской фольклористике, несмотря на ряд предпринятых исследований [Кудаева, 2019а, с. 129-136; Кудаева, 2020б, с. 230242; Хут, 1989; Ципинов, 2000 и др.], не выработана общепринятая точка зрения в вопросе определения и классификации жанров адыгской народной несказочной прозы. Решению данной проблемы, как представляется, будет способствовать системное и последовательное изучение различных жанров и жанровых разновидностей адыгской несказочной прозы. В соответствии с этим в данной статье ставится задача изучения этических преданий как одной из наименее исследованных специфических разновидностей адыгской исторической прозы.

Впервые на присутствие в адыгском фольклоре группы преданий, в основе которых лежали регулятивные функции, поддерживающие нравственно-этические нормы традиционной культуры, указывает Б. Х. Бгажноков в своей монографии «Очерки этнографии общения адыгов». «Очень часто, - отмечает он, - предания были прямо ориентированы на регуляцию поведения, на поддержание его в заданном традицией режиме. У адыгов так же, по-видимому, как и у других народов, эта форма подачи культуры общения составляла одну из граней особого жанра устного народного творчества - жанра этических, в том числе и рыцарских рассказов» [Бгажноков, 1983, с. 157]. Выдвинутое Б. Х. Бгажноковым предположение о существовании жанра «этических» или «рыцарских рассказов» не получило в его исследовании дальнейшего развития и обоснования.

В работе, посвященной народной исторической прозе адыгов, А. А. Ципинов отмечает «в структуре преданий всех групп» существование «морально-этических мотивов» [Ципинов, 2000, с. 75]. Очевидно, что морально-этические мотивы так или иначе присутствуют в различных жанрах и жанровых разновидностях как адыгской народной несказочной, так и сказочной прозы. Однако анализ всего континуума адыгской народной прозы позволил прийти к выводу о присутствии в нем целого пласта нарративов, обладающих особой функцией, заключающейся в репрезентации и утверждении нравственно-этических правил и норм, обозначенных Б. Х. Бгажноковым как «этические предания». 
Основная цель данной статьи - выявление доминирующих жанровых признаков и основных функций этических преданий, определение их места в системе прозаических жанров адыгского фольклора.

\section{2. Возникновение жанровой разновидности этических преданий}

Возникновение данной специфической жанровой разновидности преданий обусловлено особенностями общественно-исторической жизни адыгского общества, в котором на протяжении длительного исторического периода морально-этические аспекты духовной жизни формировались вне религиозных форм сознания. Религия, в частности христианство, с ее моральными, нравственными императивами (человечности, сострадания, уважения человеческого достоинства, добра, долга и т. д.), по свидетельствам миссионеров, несмотря на неоднократные попытки ее внедрения, так и не оказала существенного влияния на общественное сознание адыгских племен (миссионеры Юлиан [АБКИЕА, 1974, с. 29-33], Дортелли д’Асколи [Там же, с. 61-67], Лукка [Там же, с. 68-72], Ламберти [Там же, с. 56-60] и др.). В XVI-XVII веках, как отмечает В. К. Гарданов, причерноморские адыги хотя и считают себя христианами, «но являются такими лишь номинально» [Гарданов, 1974, с. 20].

Согласно мнению ряда европейских и отечественных путешественников и исследователей, изучавших культуру и быт адыгов начиная с XIII века [АБКИЕА, 1974], ислам на протяжении ряда веков также не оказывал сколь-нибудь значимого воздействия на адыгское общество. Однако, согласно свидетельствам А. Олеария [Там же, с. 82-85], Я. Я. Стрейса [Там же, с. 99-102], Н. Витсена [Там же, с. 86-98], А. де ла Мотрэ [Там же, с. 119-147], К. Главани [Там же, с. 156-173], религиозные верования адыгов представляли собой некий конгломерат христианских, мусульманских и языческих воззрений, в которых определяющую роль играют последние. В 70-х годах XVIII века И. А. Гюльденштедт отмечает реликты существовавших в прошлом христианских верований, подчеркивая, однако, что знатные сословия «привержены магометанскому закону», а «народ живет без религии» [Там же, с.203-208]. «Князья и дворяне, - отмечает В. Х. Кажаров, - приняв ислам, усвоили, главным образом, его внешнюю ритуальную сторону. Не будучи ортодоксальными мусульманами, они, соответственно, не испытывали потребности обращать в свою веру другие слои общества» [Кажаров, 2005, с. 35]. Изменение геополитических и социокультурных условий существования адыгского общества в связи с Кавказской войной способствовало внедрению в общественное сознание исламских верований, носивших прежде всего идеологический и политический характер. 
Отсутствие приверженности к тем или иным религиозным учениям среди адыгов обусловлено тем, что нравственно-этический, моральный аспекты духовной жизни общества компенсировались наличием сформировавшегося в адыгском общественном сознании универсального морально-правового кодекса адыгов - адыгэ хабзэ (каб.-черк.) - адыгского этикета. Было бы неверным исключать и вероятность воздействия на формирование и развитие нравственно-этического кодекса адыгов христианских и мусульманских моральных заповедей, поскольку моральный аспект религиозных учений, его гуманистическая направленность в целом соответствовали установкам и нормам адыгской этики - адыгагъэ (каб.-черк.) 'адыгства' [Бгажноков, 1999] и опирающимся на них правилам адыгского этикета - адысэ хабзэ (каб.-черк.) [Бгажноков, 1978; Бгажноков, 1983]. Мифологические воззрения адыгов, определявшие ключевые морально-этические установления и испытывавшие, по всей вероятности, также воздействие христианской и исламской морали, взаимодействовали со сформировавшейся в адыгском обществе системой нравственно-этических установок и норм (aдblгaгъэ, aдblгэ хабзэ). Они органически дополняли друг друга, составляя устойчивые идеологические, духовные и социорегуляторные компоненты традиционной культуры, нуждавшиеся в способах и механизмах их утверждения. Таким образом, возникновение и формирование жанра этических преданий были обусловлены необходимостью репрезентации и утверждения идеальных стандартов межличностного поведения, опирающихся на общепринятые в адыгском обществе нравственно-этические установки и нормы. В этических преданиях реализуется система нравственно-этических принципов и правил, нашедших воплощение в кодексе правил взаимного обхождения (адыгэ хабзэ — каб.-черк.), существовавшем также в его наиболее усложненной, сословной версии (дворянский этикет - уэркъ хабзэ - каб.-черк.) [Бгажноков, 1983]. Следует также отметить, что анализ этических преданий в этом аспекте представляется весьма продуктивным, поскольку они представляют собой уникальный источник для исследования и воссоздания не только системы нравственно-этических установок и этикетных правил, но духовной жизни традиционного адыгского общества.

\section{3. Жанровые свойства, классификация и основные мотивы этических преданий}

Этические предания, на наш взгляд, представляют собой особую жанровую разновидность исторических преданий, с присущими им «родовыми» признаками, отражающими мировоззренческие, этические принципы своего времени: историзмом, установкой на достоверность, превалирующим характером информативной функции. В пользу этого предположения 
свидетельствует то, что в основе сюжетов этических преданий, как правило, лежат исторические события и факты, а их героями являются реальные исторические личности (Хатокшоко Жамбот, Асланбек Конов, Жабаги Казаноко, князь Каноков и т. п.). Однако в центре внимания в этических преданиях находятся не героические поступки и воинские подвиги, а нравственно-этическая сфера, правила и нормы этикета. Их основная цель репрезентация идеальных форм коммуникативного поведения, фиксация примеров безукоризненного следования этическим и этикетным нормам: правилам гостеприимства, «благородной дворянской вражды», верности слову и т. д. Действия и поступки героев и персонажей этических преданий носят знаковый характер; они демонстрируют и утверждают общепринятую систему этикетных правил, определяемых этическими, моральными ценностными ориентирами.

Для этических преданий характерен ряд наиболее продуктивных, повторяющихся сюжетообразующих мотивов, репрезентирующих те или иные этические нормы и правила. Таковыми, например, являются мотивы соблюдения / нарушения правил гостеприимства, принципа верности данному слову или принятым обязательствам; следования правилам или их нарушения в мужской дружбе; следования установкам «благородной дворянской вражды», соблюдения / нарушения принципа уважения к старшим и т. д.

Мотив соблюдения / нарушения правил гостеприимства является одним из наиболее продуктивных сюжетообразующих мотивов в адыгских этических преданиях. Так, например, в одном из вариантов предания «ЕщІэнокъуэ зэшитІ» / «Два брата Ешаноковы» [Адыгэ Іуэрыуатэхэр, 1969, с. 178 - 184] к братьям Ешаноковым - Озымесу и Темиркану приезжает гость из Большой Кабарды - Жанкет. При помощи невербальных, семиотически значимых действий (спешивается с коня с левой стороны и молча входит в кунацкую - хьэщуІэщ) он дает понять, что прибыл по делу. Братья отвечают ему соответствующим образом: привязывают своих лошадей слева и справа от лошади гостя, давая понять, что он для них старший и уважаемый гость. В его честь режут скот, угощают, развлекают беседой и в течение двух недель не расспрашивают его о цели приезда (согласно правилам, гостя не расспрашивают о цели приезда в течение трех дней). Жанкет, убедившись в том, что братья безупречно следуют принятым правилам гостеприимства, объявляет, что отныне, если они не против, будет считать их своими друзьями и, поскольку наслышан об их героизме и мужестве, он, во-первых, хочет поучиться у них, а во-вторых - просит помочь ему найти невесту. В ответ братья предлагают ему прикоснуться губами к груди их матери и стать их братом. Жанкет, надев на себя непрезентабельную одежду, отправляется в сопровождении братьев на свадьбу 
во двор князя Татлостанова (Талъостэныпщ). Он подходит к сидящим во дворе за пиршественными столами и приветствует их, однако сидящие не отвечают на его приветствие. Жанкет заходит в дом, приветствует сидящего за столом князя и его гостей. Князь Татлостанов, находящийся во главе стола, настораживается, подметив, что гость не тот, за кого он себя выдает, и передает ему приветственную чашу. Один из сидящих за столом ближних уорков князя - Елбаздуко Муртазов - упрекает князя в том, что он предлагает приветственную чашу какому-то бедняку, «собакой рожденному», тем самым не только оскорбляя Жанкета, но и нарушая правила гостеприимства. Жанкет при поддержке братьев Ешаноковых, которые, согласно правилам, обязаны защищать своего гостя и во всем содействовать ему, сурово наказывают нарушителей: угоняют лошадей князя и его гостей, крадут во время свадьбы невесту, убивают бросившегося за ними в погоню князя и подвергают унижению нарушителя - Елбаздуко Муртазова. Таким образом, предание репрезентирует образец следования принятым правилам гостеприимства и наказания, следующего за их нарушением.

Соблюдение / нарушение правил гостеприимства является сюжетообразующим мотивом в предании «Лъахъэдыгъум и къуэ закъуэу Куэшхэ я фызабэм и кІалэр» / «Единственный сын Тлакодуговых, сын вдовы Кошевых» (бесленеевский текст) [Адыгэ хъыбархэр ..., 1986 с. 93-96]. Согласно сюжету, один из героев - Баг (Багъ) - приезжает в гости к князю Болотокову (Бэлэтокъуэ). Князь Болотоко принимает своего гостя, угощает его и, не предупредив о своем отъезде, отправляется в набег (зекІуэ). Болотоко отсутствует год, и все это время Баг остается в его гостевом доме. Дождавшись возвращения своего бысыма, оскорбленный Баг упрекает князя в незнании и неследовании правилам гостеприимства и предупреждает, что не простит ему этого. Чтобы проучить князя, Баг угоняет табун его лошадей, затем, остановившись, дожидается преследующего его Болотоко. Угон табуна в данном случае преследует цель вызвать противника на поединок. Мотив нарушения правил гостеприимства в предании дополняется мотивом «благородной дворянской вражды», в соответствии с правилами которой противники приветствуют друг друга, ведут переговоры и предлагают друг другу право первого выстрела: Къауэ Багъ, дu псальэм кІьхь зомьгъэщуІу, льэныкъуитІьли гуп къыложьэ. - Сэ уишъри къэсхуу, икІи япэ сыноуэу къекІукъым, джиІэри идакъым / «Стреляй Баг, не нужны длинные разговоры, нас ждут наши спутники. - Я и лошидей твоих угоняю, и при этом ещче и стрелять первым - это нехорошо»отвечает Баг. Он, однако, знает, что Болотоко отличный стрелок и что если он выстрелит первым, то убьет его, но тем не менее следует принятым правилам, предлагая право первого выстрела противнику. Болотоко, 
оценив мужество и благородство Бага и понимая, что оскорбил его, нарушив нормы гостеприимства, приносит Багу извинения.

Мотив мужской дружбы, предписывающий выполнение принятых дружеских обязательств, - один из популярных мотивов адыгских этических преданий. Так, например, герой предания «Сальпы жари зылІ щыІа ...»/ «Жил один мужчина [по имени] Сальпы» [Адыгэ хъыбархэр ..., 1986, с. 58-59] Жамбот Хатокшоко помогает своему другу умыкнуть его возлюбленную прямо во время свадьбы и жертвует своей жизнью, отвлекая их преследователей на себя. В предании этот мотив сопряжен с мотивом гостеприимства, предписывающим в любых обстоятельствах оказывать уважение к гостю. В ходе столкновения с преследователями Жамбот отказывается стрелять в юного сына князя Канокова, мотивируя это тем, что тот слишком молод («Я не смешиваю кровь и молоко») и погибает от его руки. Тела двух погибших сыновей князя и тело Жамбота доставляют в дом Каноковых и кладут на почетное место, а тело Жамбота - у дверей. Княгиня Канокова приказывает перенести тело их погибшего противника - Жамбота - на почетное место, сопроводив словами: «АтІэ, езыр кІуэда шихьэкІэ, хабзэр кІуэдын хуейкъымм» / «Хоть он и погиб, но хабзэ [закон гостеприимства] погибнуть не должен» [Адыгэ хъыбархэр, 1986, с. 59].

Мотив, воплощающий принцип уважения к старшим, к родителям, один из наиболее продуктивных в этических преданиях. В наиболее выразительной форме этот мотив представлен в предании о Кербече, сопровождающем одноименную плачевую песню («Кербеч»). Смертельно раненый герой Кербеч, чувствуя приближение смерти, выражает желание проститься со своим отцом, с которым он до той поры никогда не говорил (одно из правил, отображавших принцип уважения к отцу). В соответствии с правилами этикета в присутствии отца сын не должен сидеть и тем более лежать в постели. Однако Кербеч ослаб и уже не может встать на ноги. Он просит принести ему веревку и перебросить один ее конец через потолочную балку, другим концом обвязывает себя и, натягивая веревку, поднимает себя, «стоя», встречает отца, прощается с ним и вскоре умирает.

Для этических преданий характерен мотив благородного, уважительного отношение к женщине. Например, в предании «Хабар о Хадидже» [Кабардинский фольклор, 1936, с. 340-344], которой за ее мудрость было решено отдавать долю, причитающуюся каждому участнику набега. Мотив уважения к женщине, сочетающийся с демонстрацией удали и ловкости, воплощен в предании «Щоджэн Шумахуэрэ Хъырцыжьымрэ ящІа тельыджэ» / «Удивительное, что совершили Шоджен Шумахо и Хырциж» [Адыгэ хъыбархэр ..., 1986, с. 92-93]. Герои предания, Шоджен Шумахо и Хырциж, проникают в воинский гарнизон и умыкают дочь русского гене- 
рала. Девушку содержат на правах почетной гостьи, кана (воспитанницы) и названной сестры, ей оказывают знаки внимания, развлекают, угощают лучшими блюдами. По прошествии года девушке дарят адыгский национальный наряд: расшитую золотым шитьем шапочку, украшенное серебряным нагрудником, подпоясанное поясом, отделанным золотом и серебром, платье - и с почестями в сопровождении верховых препровождают к отцу-генералу. Девушка рассказывает отцу, что она была названой сестрой для своих похитителей. Генерал спрашивает, какое вознаграждение они бы хотели. «Зы дыхуейкъым, быльми сыти, пари дыхуэныкъуэкъым, ауэ благъэ утмцьну нэхъ» / «Ничего нам не нужно, ни скот, ничего, мь ни в чем не нуждаемся, хотим только, чтобы мы стали родственниками», отвечают они. «Абдежра, жи, къыщщаублар зэхыхьэу, адыгэмрэ урысылмрэ зхьххээу къыщцаублар» / «С этих пор, говорят, начали адыги и русские общуаться друг с другом», — заключает предание [Там же].

Сюжетообразующим в ряде вариантов предания является «мотив остающегося на условленном месте / в карауле героя» (предание о Хату Анзорове), который призван продемонстрировать пример выдержки и верности взятым на себя обязательствам. Так, например, в предании «Пщы дэгъазэ» / «Сопровождение князя» [Архив КБИГИ, паспорт № 5] уорк (дворянин) Асланбек Конов вместе со своим сопровождающим проезжает мимо селения, где живет семья последнего. Тот просит отпустить его навестить мать и обещает тотчас же вернуться. Однако, забыв о данном обещании, возвращается только наутро и застает Асланбека Конова, который, не сдвинувшись с места, сидя верхом на коне, ожидает его. В другом варианте данного сюжета героем, который также не двигается с места в ожидании своего спутника, выступает Жабаги Казаноко. Спутник Жабаги, сказав, что должен навестить кого-то, ненадолго оставляет его, но, поддавшись уговорам, остается в гостях до утра. Возвратившись наутро, видит, что Казаноко стоит, ожидая его, там, где они расстались. «Жэбагъы къыщагъэнам къыщагъуэтыж» - «Жабаги находят там, где оставили» [Къэзэнокъуэ Жэбагъы ..., 2001, с. 91-92] / Конь его выбил землю передними копытами и погрузился в землю до бабок, а сам он стоит, повернувшись спиной к ветру и снегу, и бурка его вся покрыта снегом. «А, ... ты еще стоишь здесь?» - спрашивает его спутник, и Жабаги отвечает: «Ах ты, сукин сын, слыхал ли ты, чтобы Жабаги не нашли в том месте, где его оставили?» - отвечает герой.

Приведенные выше мотивы и сюжеты этических преданий не исчерпывают всю их полноту; более обстоятельное их изучение представляет собой задачу дальнейшего исследования.

Следует отметить, что этические предания включают в себя произведения разностадиального характера. К наиболее архаическим из них 
относятся различные варианты цикла преданий о братьях Ешаноковых: «ЕщІэнокъуэ Атэбий и къуитI Уэзырмэсрэ Темыркъанрэ я таурыхъ» / «Предание о двух сыновьях Атабия Ешанокова, Озырмесе и Темиркане» [Адыгэ ІуэрыІуатэхэр, 1969, с. 156-160]; «ЕщІэнокъуэ зэшитІ» / «Братья Ешаноковы» [Там же, с. 178-184]; «ЕщІэнокъуитІым я хъыбар» / «Предание о двух сыновьях Ешаноковых» [Там же, с. 171-175] и др. Фактологическая основа наиболее архаического пласта преданий не очевидна, в них описываются события отдаленного прошлого, которые не могут быть, как правило, подтверждены историческими источниками. Однако их достоверность не вызывает ни у исполнителей, ни у реципиентов сомнений. В качестве героев преданий могут выступать как полулегендарные, так и реальные персонажи. Например, о главных героях преданий братьях Ешаноковых, об их друге Жанкете исторические сведение практически отсутствуют, однако у образов их противников - князя Татлостанова (Талъостэныпщ), уорка (дворянина) Елбаздуко Муртазова имеются реальные исторические прототипы. Сопоставление нравственно-этических норм, находящих воплощение в архаическом пласте этических преданий, с этими же правилами в более поздних текстах преданий позволяет проследить динамику происходящих изменений в данных нормах. Так, например, убийство Атабием - отцом братьев Ешаноковых - спящего противника князя Татлостанова или Куйцука Дагужея (КъуийцІыкІу и къуэ Дэгужьей) («ЕщІэнокъуэ Атэбий» / «Атабий Ешаноков») [Там же, с. 121, с. 182] в более поздних преданиях считается недопустимым нарушением кодекса чести.

Для более поздних этических преданий характерен качественно иной, конкретно-исторический способ отображения действительности. В них описываются реальные события, героями и персонажами этих преданий являются исторические личности, прославленные герои, воины: Жамбот Хатокшоко, Баг, князь Каноко, Гудаберд, сын Азепша, Балотоко, Кербеч, Асланбек Конов, народный мудрец Жабаги Казаноко и др. В них могут присутствовать указания на географическое место описываемых событий, придающие достоверность изложению. Так, например, предание «Лъахъэдыгъум и къуэ закъуэу Куэшхэ я фызабэм и кІалэр» / «Единственный сын Тлакодуговых, сын вдовы Кошевых» (бесленеевский текст) начинается с описания географического расположения владений Бага и мест проживания различных адыгских народностей: Шьокъуракъ къуэладжэм, Уарпрэ Инджыджрэ я зэхуакум, Багъым и джылэр дэса. Абы ящххьэмкІэ абазэххэр дэса. Беслэнейхэм я икІахэми абазэххэр куэду псэуа. Лабэ псыхъуэ адырыкІьым кІэмыргуейхэмрэ бесланейхэмрэ я кІыъыгу зэпьльа / В долине Шокурака, в междуречье Уарпа и Инджиджа находились селения Бага. Выне них жили абазехи. На землях бесланеевцев тоже жило много абад- 
зехов. На другом берегу Лабы располагались земли кемиргоевиев и бесланеевиев [Адыгэ ..., 1986, с. 93].

Особую группу представляют собой этические предания цикла о Жабаги Казаноко, с которым связывается появление и утверждение новых правил адыгского этикета. В частности, согласно преданию «Гупмахуэбжьэр зылъысыр хэт?» / «Кому предназначен гупмахобжа? [букв. 'приветсвенный рог']», Казаноко вводит правила принятия приветственной чаши во время застолья [Къэзэнокъуэ Жэбагъы ..., 2001, с. 100]. В предании «Щыхьэкуэхэм я хабзэ» / «Обычай горевестников» [Там же, с. 87] описывается введение невербальной, семиотически значимой формы извещения родственников о смерти их близких. Согласно сюжету предания, в отсутствие Жабаги умирает его жена и никто не решается взять на себя тяжесть сообщения ему горестной вести. Тогда один старик предлагает: Жэбагъbl езыр лІь ущзщ, зыри щІыжефІэн щыІэкъым. ФыкІуи Жэбагъы илъагъу ижьырабгъумкІэ фыщепсых. Зыри жывмылэу ижьырабгъумкІэ фыщепсыхи фыкІуж / Жабаги сам мудрый муж, ничего не надо ему говорить. Поезжайте, и так, чтобы Жабаги видел, спешьтесь с правой стороны. Ничего не говоря, садитесь на коня с правой стороны и приезжайте [Там же, с. 86-87]. Горевестник приезжает и делает все так, как посоветовал старик. Все в недоумении, не понимают, почему всадник так повел себя и по-разному истолковывают его поведение. И только Жабаги понимает, что ему принесли весть о смерти его жены: Абы и дежым къыщаублащ щхьакІуэ кІуэр ижьырабгъумкІэ епсыхыу, ижьырабгъумкІэ иэсыжу / С тех пор и пошло: кто едет извещать о горе, спешивается с правой стороны и садится на коня с правой стороны [Там же, с. 87].

В более поздних этических преданиях из цикла о Жабаги Казаноко (конец XVII - середина XVIII веков) наблюдается процесс трансформации, происходящий в отображаемой ими нравственно-этической и этикетной сферах. Общим для этой группы преданий является утверждение приоритета морально- нравственных норм над правилами этикета. Так, в различных вариантах преданий, объединенных составителями в тематическую группы «Фызым зэрыхущыт» / «Отношение к женщине», например, «Жэбагъы и фызым пщІэ щІыхуищІыр» / «Почему Жабаги ценит жену» и др. [Там же, с. 106-112], Жабаги Казаноко демонстрирует пренебрежение правилами гостеприимства (мотив расчесывания волос девочке, перевязывания ножки козленку и т. п.) и обосновывает нравственный приоритет созидательного труда, дела, заботы о ближних над слепым следованием правилам этикета, при этом избираются парадоксальные формы и решения. Правила поведения в подобных случаях интерпретируются и согласуются не на уровне принятых стандартов поведения, а в соответствии с суще- 
ствующими нравственно-этическими нормами. Столкновение этих уровней (этика - этикет), нашедшее воплощение в преданиях, способствовало дальнейшему развитию и регуляции всей структуры нравственно-этических норм и правил этикета, этого сложного механизма, образующего духовный стержень адыгской традиционной культуры.

\section{4. Герои и персонажи этических преданий}

Герои этических преданий представлены образами двух типов. Первый - тип идеального героя, безукоризненно, «с особым изяществом, с преодолением сложных внешних и внутренних препятствий» [Бгажноков, 1983, с. 157] выполняющего правила и установки адыгского этикета. Например, Хотокшоко Жамбот в упоминавшемся предании «Салъпы жари зылI щыІа ...» / «Жил один мужчина [по имени] Сальпы» [Адыгэ хъыбархэр ..., 1986, с. 58-59]), Асланбек Конов и Жабаги Казаноко («Пщы дэгъазэ» / «Сопровождение князя»; «Жабагъы къыщагъэнам къыщагъуэтыж» / «Жабаги находят там, где оставили») [Къэзэнокъуэ Жэбагъы ..., 2001, с. 92], Баг в предании «Лъахъэдыгъум и къуэ закъуэу Куэшхэ я фызабэм и кІалэр» / «Единственный сын Тлакодуговых, сын вдовы Кошевых» [Адыгэ хъыбархэр ..., 1986, с. 93-96]; Кербеч в предании, сопровождающем песню («Къербэч и гъыбзэ» / «Плач о Кербече») [Адыгэ уэрэдыжьхэр, 1979, c. 69-70; 189-190]; Жанкет и братья Ешаноковы, абрек Гулей в предании «Гулей», который, окруженный врагами, предлагает право первого выстрела своему преследователю [Кабардинский фольклор, 1936, с. 270-272]; Хырцыж (Хъырцыжь) в предании «Сосрэн и къуэр, Кушукупщ, Хьэтхым и къуэ кІасэр, Хъырцыжь и къуэр» / «Сын Сосреша, Кушукупщ, поздний сын Хатха, сын Хырцыжа» [Адыгэ хъыбархэр ..., 1986, с. 85-92] и др.

Второй тип - это отрицательные персонажи, нарушающие принятые этикетные и этические нормы, которые заслуживают осуждения, порицания, а зачастую - и сурового наказания, как, например, скупой хозяин в предании «ХьэщІэмыгъашхэ» / «Не кормящий гостей» [Там же, с. 257258] Елбаздуко Муртазов - антигерой предания о братьях Ешаноковых, князь Кейтуко в предании «Пщы и пщыж Къетыкъуэ и кІуэдыжыкІар» / «Как был уничтожен князь князей Кейтыко», «Елмырзэхэрэ Къарамырзэхэрэ зэрызыщыхьа щІыкІэр» / «Как поссорились Эльмурзовы и Карамурзовы» [Архив КБИГИ, паспорт 12] и т. п.

«Идеальный герой» этических преданий демонстрирует как общеизвестные стандарты действий и поступков, так и ситуативно усложненные, порой противоречивые и требующие не только знания общепринятых правил этикета, но и тонкого анализа ситуации, виртуозной интерпретации правил и их ситуативного применения. Сюжет таких этических преданий призван на- 
глядно представить весь спектр этикетных правил и нравственно-этических аргументов, которыми определяется и обосновывается логика выбора тех или иных действий и поступков персонажа. Например, в предании о Гудаберде, сыне Азепша, сопровождающем песню «Азэпщ и къуэ Гъудэберд» / «Гудаберд, сын Азепша» [Народные песни ..., т. III, ч. 2, с. 360-365], герой, не желающий нарушать принцип «недоносительства», обвинен в убийстве князя и вынужден покинуть родину (cblмыхээээн щзхьэк1э хэкур собгынэ / чтобы не стать доносчиком - родину покидаю). Вынужденный вернуться, он оказывается перед дилеммой: стать жертвой кровной мести или быть убитым настоящими виновниками преступления. Чтобы очистить свое имя, он приходит в кунацкую семью убитого князя и поет «очистительную песню», в которой утверждает свою непричастность к злодеянию и при помощи намеков и иносказаний указывает на настоящих убийц.

\section{5. Заключение}

Таким образом, этические предания, как и другие жанры фольклора, включают в сферу своего художественного обобщения мировоззрение народа, факты его истории, использует обусловленные различными этапами развития поэтического сознания эстетические принципы и методы обобщения действительности. В этических преданиях находит воплощение опыт многих поколений, и их изучение позволяет глубже понять особенности национальной традиционной культуры, выявить ее мировоззренческие и эстетические ориентиры. Они отражают историческую, духовную и общественную жизнь народа и наряду с другими произведениями фольклора служат важным источником для исследования и понимания мировоззренческих основ традиционной духовной культуры, основных принципов и особенностей художественного творчества. Адыгские этические предания сформировались и функционировали как органический элемент духовной и социальной жизни традиционного адыгского общества. Как явление фольклора они представляют собой одну из жанровых разновидностей народной исторической прозы; обладают сходными с историческими преданиями способами и формами жанровой организации. Вместе с тем для этических преданий характерна особая проблематика, своеобразный набор повторяющихся сюжетных мотивов и образов. Дифференцирующим признаком этических преданий является их когнитивная и социорегулятивная функции. Репрезентируя предпочтительные формы общественного поведения, этические предания утверждали общепринятые моральные, этические нормы и правила, способствовали формированию общезначимых мировоззренческих установок, способствуя, в отсутствие развитой государственности и письменных юридических норм, нормализации и стабилизации общественной жизни. 


\section{ИСТОЧНИКИ И ПРИНЯТЫЕ СОКРАЩЕНИЯ}

1. АБКИЕА - Адыги, балкарцы и карачаевцы в известиях европейских авторов XIII-XIX вв. / сост., редакция переводов, введение и вступ. статьи к текстам В. К. Гарданова. - Нальчик : Эльбрус, 1974. - 635 с.

2. Адыгэ хъыбархэр (Адыгские (черкесские) народные новеллы / сост. и вступ. ст. М. И. Мижаева). - Черкесск, 1986. - 360 с.

3. Aдыгэ ІуэрыІуатэхэр : в 2-х т. / Зэхэзылъхьар КъардэнгъущІ Зырамыкущ. (Aдыгский фольклор / сост. 3. П. Кардангушев). — Налшык : Къэб.-Балък.тх.тедз., 1963. T. $1 .-339$ с. ; 1969. - T. 2. - 412 с.

4. Адыгэ уэрэдыжьхэр / Зыхуэзыхьэсыжар КъардэнгъущI Зырамыкущ (Адыгские старинные песни / сост. 3. П. Кардангушев). — Налшык : Эльбрус, 1979. — 223 с.

5. Архив КБИГИ. Ф. 12. Оп. 1. Папка № 23-е. Паспорт № 5 ; Оп. 1. Папка № 19. Паспорт 12.

6. Кабардинский фольклор / общ. ред. Г. И. Бройдо ; ред. Ю. М. Соколова ; вступ. ст., коммент. и словарь М. Е. Талпа. - Москва-Ленинград : Academia, 1936. — 650 с.

7. Къэзэнокъуэ Жэбагъы и хъыбархэр (Сказания о Жабаги Казаноко / сост. и коммент. 3. М. Налоева, А. М. Гутова). - Нальчик : Эль-Фа, 2001. - 329 с. (На каб.-черк. яз.).

8. Hародные песни и инструментальные наигрыши адыгов : в 3-х т. / подгот. к печ. 3. П. Кардангушева ; главн. ред. Е. В. Гиппиус. - Москва : Советский композитор, 1981. - T. I-II.

\section{ЛИТЕРАТУРА}

1. Альборова Л. И. Адыгская этика и первичная социализация в традиционной системе воспитания / Л. И. Альборова. - Нальчик : Полиграфсервис и Т, 2002. - 136 с.

2. Бгажноков Б. Х. Адыгская этика / Б. Х. Бгажноков. — Нальчик : Эль-Фа, 1999. — 96 с.

3. Бгажноков Б. Х. Адыгский этикет / Б. Х. Бгажноков. - Нальчик : Эльбрус, 1978. - $160 \mathrm{c}$.

4. Бгажноков Б. Х. Очерки этнографии общения адыгов / Б. Х. Бгажноков. - Нальчик : Эльбрус, 1983. - 229 с.

5. Бгажноков Б. Х. Этика Ж. Казаноко и духовная атмосфера Кабарды в XVIII столетии / Б. Х. Бгажноков // Жабаги Казаноко : материалы региональной научной конференции (30-31 октября 1985 г.). - Нальчик : Эльбрус, 1987. - С. $23-49$.

6. Гарданов B. K. Введение / В. К. Гарданов // Адыги, балкарцы и карачаевцы в известиях европейских авторов XIII-XIX вв. / сост., редакция переводов, введение и вступ. статьи к текстам В. К. Гарданова. - Нальчик : Эльбрус, 1974. - С. 3-28.

7. Кажаров B. X. Песни, ислам и традиционная культура адыгов в контексте Кавказской войны / В. Х. Кажаров //Адыгские песни времен Кавказской войны. - Нальчик : Эль-Фа, 2005. - С. 29-86.

8. Кудаева 3. Ж. Жанровые свойства и типы адыгских топонимических преданий / 3. Ж. Кудаева, Л. С. Хагожеева // Научный диалог. - 2020. - № 8. - С. 230-242. DOI: $10.24224 / 2227-1295-2020-8-230-242$.

9. Кудаева 3. Ж. Легенды : к проблеме определения и классификации жанров адыгской несказочной прозы / З. Ж. Кудаева // Вестник Адыгейского государственного университета. Серия 2 : Филология и искусствоведение. - 2019. — № 4 (247). — С. 129-136.

10. Хут Ш. Х. Несказочная проза адыгов / Ш. Х. Хут. — Майкоп, 1989. - 336 с. 
11. Ципинов А. А. Народная историческая проза адыгов / А. А. Ципинов. - Нальчик : Эль-Фа, 2000. — 157 с.

\section{MATERIAL RESOURCES}

ABKIEA - Adygs, Balkars and Karachays in the news of European authors of the XIIIXIX centuries. (1974). Nalchik: Elbrus. 635 p. (In Russ.).

Adyghe (Circassian) folk novels. (1986). Cherkessk. 360 p. (In Adyg.).

Broido, G. I. (ed.) (1936). Kabardian folklore. Moscow-Leningrad: Academia. 650 p. (In Russ.).

Folk songs and instrumental tunes of the Adygs: in 3 volumes, I-II. (1981). Moscow: Soviet Composer. (In Russ.).

Kardangushev, Z. P. (1963). Adyghe folklore: in 2 t., 1, 2. Nalshyk: Keb.-Balk. tkh. tedz. (In Adyg.).

Kardangushev, Z. P. (1979). Adyghe old songs. Nalshyk: Elbrus. 223 p. (In Adyg.).

KBIGI archive. F. 12. Op. 1. Folder № 23-E. Passport № 5; Op. 1. Folder № 19. Passport 12. (In Adyg.).

Tales of Zhabagi Kazanoko. (2001). Nalchik: El-Fa. 329 p. (In Kab.-Cherk.).

\section{REFERENCES}

Alborova, L. I. (2002). Adyghe ethics and primary socialization in the traditional system of education. Nalchik: Polygraphservice and T. 136 p. (In Russ.).

Bgazhnokov, B. H. (1978). Adyg etiquette. Nalchik: Elbrus. 160 p. (In Russ.).

Bgazhnokov, B. H. (1983). Essays on the ethnography of communication of the Adygs. Nalchik: Elbrus. 229 p. (In Russ.).

Bgazhnokov, B. H. (1987). Ethics Zh. Kazanoko and spiritual atmosphere of Kabarda in the XVIII century. In: Zhabaghi Kazanoko: materials of the regional scientific conference (October 30-31). Nalchik: Elbrus. 23 - 49. (In Russ.).

Bgazhnokov, B. H. (1999). Adyg ethics. Nalchik: El-Fa. 96 p. (In Russ.).

Gardanov, V. K. (1974). Introduction. In: Circassians, Balkars and Karachais in the proceedings of European authors XIII-XIX. Nalchik: Elbrus. 3-28. (In Russ.).

Huth, S. H. (1989). The fairy-tale prose of the Adyghe. Maikop. 336 p. (In Russ.).

Kazharov, V. Kh. (2005). Songs, Islam and traditional culture of the Adygs in the context of the Caucasian War. In: Adyghe songs from the time of the Caucasian War. Nalchik: El-Fa. 29-86. (In Russ.).

Kudaeva, Z. Zh. (2019). Legends: on the problem of determining and classifying genres of Adyghe non-fairy prose. Bulletin of the Adygea State University. Series 2: Philology and Art History, 4 (247): 129-136. (In Russ.).

Kudaeva, Z. Zh., Khagazheev, L. S. (2020). Genre Features and Types of Adyghe Toponymic Legends. Nauchnyi dialog, 8: 230-242. DOI: 10.24224/2227-1295-2020-8230-242. (In Russ.).

Tsipinov, A. A. (2000). Folk historical prose of the Adygs. Nalchik: El-Fa. 157 p. (In Russ.). 